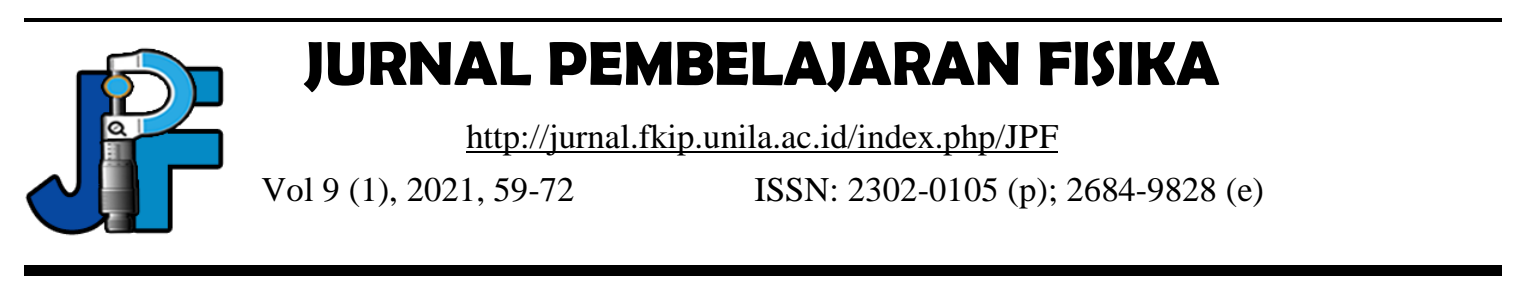

\title{
Self-Regulated Learning Strategy Based on Problem Solving to Improve The Learners' Learning Outcomes
}

\author{
Santi Eka Ambaryani ${ }^{1 *}$, Winarti Winarti ${ }^{2}$ \\ ${ }^{1}$ The Physics Education Department, Master of physics education, Faculty of Teacher Training and \\ Education, Sebelas Maret University, Surakarta Indonesia \\ ${ }^{2}$ Physics Education Department, UIN Sunan Kalijaga Yogyakarta, Indonesia \\ *e-mail: ambaryani_santi14@student.uns.ac.id
}

Published: July 19, 2021

\begin{abstract}
Self-regulated learning is an effort to manage an individual's learning. This research aims to 1) determine the strategy of self-regulated learning (SRL) based on problem-solving toward the learners' learning outcomes and 2) determine the learning outcome improvement of the learners in learning by using the SRL based-problem solving. This research is quantitative research with quasi-experimental type and pretest-posttest control group design. The sampling technique was purposive sampling. The research population covered all in Senior High School (SMA 5) Yogyakarta. The samples were from the tenth graders of Mathematics and Science Program 3 as the control group and Mathematics and Science Program 1 as the experimental group. The data collection methods consisted of test and non-test. The analysis result were, the hypothesis test showed that the applied strategy influenced the learners' learning outcomes and the learners' learning outcomes had improvements with the N-gain average score of 0.590 , categorized moderate.
\end{abstract}

Keywords: Problem-Solving, Self-Regulated Learning Strategy, Simple Harmonic Motion

DOI: http://dx.doi.org/10.23960/jpf.v9.n1.202106 


\section{INTRODUCTION}

The success of an educational institution in promoting education to achieve the national education goal depends on the classroom learning process. Anggo (2011) argues that appropriate learning strategy implementation based on the learners' characteristics could direct their thinking skills. Thus, an active, creative, and dynamic learning process can occur to reach the optimum learning outcomes. It is also important to encourage the learners' skills in solving problems. Santrock (2007) revealed that the learning process could bring a relatively permanent influence for both behavioral, cognitive, and thinking skill aspects of learners. Therefore, appropriate learning strategies need to be applied in order to support the development of students' thinking skills

Lestari, et al. (2017) found that learning was not only about transferring knowledge. Teaching should be a conscious effort of learners to learn. A conscious learner could plan properly to reach excellent outcomes. Rerung, et al. (2017) revealed that physics was not only a set of knowledge about facts, concepts, or principles but it deals with the learning process that provides direct experience for the learners to understand the surrounding nature scientifically. Thus, the physics learning process not only brings students to know nature, but also encourages them to participate in planning the learning process.

Self-regulated learning (SRL) is a learning strategy with metacognitive skill indicators during its syntax promotion. Lee \& Baylor, (2006) emphasize metacognition as skills to recognize and monitor an individual's thinking. Thus, his metacognition process will be different from other individuals based on his skills. Livingston (2003) argues that cognitive process implementation could be realized by devising a plan by controlling the metacognition in successful learning. SRL is an important factor in the learning process and learning outcomes (Sulisworo, et al., 2020). Learners with managing and controlling skills for learning are categorized to have metacognition (Iskandar, 2014). Every individual will develop his monitoring stage in learning (Nahdi $\&$ Juju, 2016). The learning process should lead to a final score to measure the material understanding skills (Friskilia \& Winata, 2018). Susanto (2013) argues that a successful level should be stated in scores that are obtained from test results. The terms metacognition, self-regulation, and autonomous learning frequently appear in educational literature and are used interchangeably. Many studies about perception or misperception due to the broader implementation have been done at various educational levels. They aimed to explore the theoretical and empirical limitations of the three constructions (Blakey \& Spence, 1990; Tan, 2004). SRL is an alternative to be a suitable learning strategy to improve the learners' learning outcomes.

Chairani (2013) argues that if an individual encounters a mathematics problem, he will think about how to solve the problem. The encouragement to solve problems would trigger ideas to prepare and plan the strategies and to solve the problems. The skill to develop is called self-regulation. It is an aspect of metacognition knowledge (Qohar \& Sumarmo, 2013). Students who have high metacognition try to learn things that will become their learning activities easily and get high results, know and use appropriate, efficient strategies, according to conditions in order to achieve learning goals (Ayu, et al., 2014). In addition, problem-based learning will also raise students' 
ability to use their scientific concepts in answering problems by presenting supporting evidence as reinforcement (Agusni, et al., 2017). Gagne (1985) argues if an individual encounters a problem, he will not only solve the problems but also learn something new. It can be understood that problem-based learning can not only train problem solving skills, but also students can gain new knowledge.

According to Yanti, et al., (2017), the application of metacognition-based learning in physics learning will make it easier for students to solve physics problems. Zimmerman (1989) explains that self-regulation is an individual process to activate and maintain cognition, behavior, and achievement-oriented systematic influence of learners. Armelia \& Ismail (2021) states that SRL encourages students to control themselves and are given the freedom to express themselves, so that in doing learning students can show their best abilities and do not feel forced. SRL is able to improve students' ability to plan goals, plan strategies, manage behavior, and evaluate selfimprovement (Winiari, et al., 2019). When SRL is applied, learners can improve their skills to remain honest, independent, and courageous. It also allows students to experience new things to check their weaknesses and strengths in learning science. Thus, their learning outcomes will be achieved.

Lin \& Singh (2011) state that problem-solving does not refer to skills to identify the applied principles in solving problems but also the skill to apply what is learned. It is from the identification into the new situation with different representations or features. Saputra, et al., 2019) state that teachers must be aware of appropriate problemsolving approaches based on the learners' needs. The eligible learners to solve problems with a qualitative approach would understand the formulas. On the other hand, learners with an excellent understanding of calculation should be encouraged to understand something orally.

The problem-solving process cannot be separated from the problem-solving stages. The adopted problem solving was IDEAL problem-solving based on Bransford \& Stein (1993). This problem solving is established from the skills to identify problems, determine the objectives, recheck, and learn from the problem solving promoted based on scientific attitudes.

Adolphus, et al., (2013) found that learners with a low understanding of scientific terms would perform lower in identifying the parameters to calculate and have lower confidence. The logic of thinking that is less trained and the lack of involvement in everyday experience also affects students' reasoning in understanding the lesson (Himawan, et al., 2020). Harmonic vibration concept is contextual and closely related to everyday life (Malik, et al., 2019). Sugara, et al. (2016) found many learners still had difficulties understanding the concept of simple harmonic motion. Merhar, et al. (2009) found that learners also had difficulties determining the direction changes from oscillating objects. The results of Mahen \& Nuryanti (2018) research show that as many as $82.9 \%$ of research subjects are categorized as low in understanding the concept of simple harmonic vibrations. Himawan \& Winarti (2018) found that the standard of material mastery depended on problem-solving skills. Therefore, integrating problem solving related to everyday life is needed in teaching the concept of simple harmonic vibrations, so that students better understand the concept.

Based on the observation of physics learning, Senior High School (SMA 5) 5 Yogyakarta had not been applied Learning SRL as the solution to improve the learners' 
metacognition skills. The achieved learning outcomes of the learners had not been as expected especially about the material of simple harmonic motion. Many learners had not accomplished the minimum mastery standards of simple harmonic motion. It was due to many equations and materials to understand while the learners could not define the initial problem-solving stage of the question exercise and connect the appropriate equation for the questions. Rahayu \& Hertanti (2020) revealed the necessity to find the correlation between metacognitive awareness and problem-solving skills quantitatively, especially in physics learning.

Based on the interview, the learners' had difficulties understanding and connect the presented data on the question sheet toward the applied equation to solve the problems. The observation results of the learning activities showed that learners were less active during the learning. They had not been habituated and could not determine what strategies to apply to solve the problems. They tended to wait for the answers and explanations of the teachers. They also could not find the solution first. This situation made the teachers ignorant and did not retry or promote self-evaluation. It showed that the ongoing learning activities had not facilitated the thinking skills in solving problems and controlling their cognitive activities. It meant they had not met the self-regulation criteria.

From the explanation, an SRL-based problem-solving strategy must be applied in simple harmonic motion material. Thus, learners could improve their learning outcomes and monitor their skills to determine the initial stage in solving physics problems. Therefore, this research aims to find out the influence of SRL-based problemsolving strategy to solve the simple harmonic motion toward the learners' learning outcomes.

\section{METHOD}

\section{Research Design \& Procedures}

This research is quasi-experimental. It took place in Senior High School (SMA 5) Yogyakarta in the even semester, the academic year 2019/2020. The research procedure was initiated by providing a pretest to find out the initial skill of the learners. The second stage was - treating the learners with a self-regulated learning strategy starting from the orientation of learning objectives, self-control, motivation in solving problems and evaluating learning outcomes. After that, the posttest was given to determine whether they had improvements in understanding the physics materials or not. The applied research design is a pretest-posttest control group design.

\section{Population and Sample}

The research population took all tenth graders of the Mathematics and Science Program of Public Senior High School (SMA 5) Yogyakarta. The learners were studying the simple harmonic motion material. The population consisted of all classes that study simple harmonic motion, six classes. The total number of learners in the classes was 216 individuals.

The applied sampling technique was nonprobability sampling with purposive sampling technique. Two classes were selected as the sample. They were the tenth 
graders of Mathematics and Science program 3 as the control group and the learners from Mathematics and Science program 1 as the experimental group. The procedure of treating the groups is shown below.

Table 1. The Treatment Design

\begin{tabular}{cccc}
\hline Groups & Pre-Test & Treatment & Post-test \\
\hline $\begin{array}{c}\text { Experimental } \\
\text { Group }\end{array}$ & $\mathrm{Y}_{1}$ & $\mathrm{O}$ & $\mathrm{Y}_{2}$ \\
$\begin{array}{c}\text { Control } \\
\text { Group }\end{array}$ & $\mathrm{Y}_{1}$ & $\mathrm{O}_{1}$ & $\mathrm{Y}_{2}$ \\
\hline
\end{tabular}

\section{Data Collection and Instrument}

The data collections were test and non-test techniques. The test technique was a test method. The test instrument consisted of 10 question items. The questions were essays. They were grouped into 2 packages. The researchers divided it into two packages to lose the learners' burdens, to make them focus, and to assess objectively. The A package consisted of 5 questions while the B package consisted of 5 questions with skill achievement indicator adjustments. On the other hand, the applied technique was observation. The observation interview used an observation sheet for the learners and a self-regulation journal. The instruments were to obtain the learning process reflection data.

\section{Data Analysis}

The researchers analyzed the learning outcome data of learners in solving problems quantitatively, with descriptive and inferential statistics analysis assisted by SPSS. The descriptive analysis consisted of an instrument test. It was a validity test with the V-Aiken formula (Aiken, 1980). Then, the researchers conducted the required test. The test consisted of a normality test with Shapiro Wilk and a homogeneity test with Levene test assisted by SPSS 15.0. The researchers tested the hypotheses with Mann Whitney test, assisted by SPSS 15.0. Fourth, the problem-solving skill improvements were analyzed with the N-gain score.

\section{RESULT AND DISCUSSION}

The requirement test had a purpose to determine the statistics to analyze the research data. If the data were normally distributed, then the researchers had to use the parametric statistics method. However, if the data were not normally distributed, the statistics method would be non-parametric. The requirement test consisted of normality and homogeneity tests. The normality test took the pre-test scores of the problemsolving skills from both groups with Shapiro Wilk. The test results are shown in Table 2 .

Table 2. The Normality Test of Pretest Results of the Learners' Problem-Solving Skills with Shapiro Wilk

\begin{tabular}{cccc}
\hline Groups & Shapiro Wilk & Df & Sig. \\
\hline
\end{tabular}




\begin{tabular}{llll}
\hline Experimental & & & \\
$\quad$ Group & 0.890 & 36 & 0.002 \\
Control Group & 0,912 & 36 & 0.007 \\
\hline
\end{tabular}

The pretest score normality could be determined by comparing the result and the significance, 0.05 . If the result is higher than 0.05 , the data are normally distributed and vice versa. Table 2 shows the normality data test of the pretest results. The significance score of the experimental group is 0.002 and the control group is 0.007 . The scores are lesser than 0.05 , meaning that the pretest scores were not normally distributed. The test results are shown in Table 3.

Table 3. The Normality Test of Post-test of the Learners' Problem-Solving Skills with Shapiro Wilk

\begin{tabular}{cccc}
\hline Groups & Shapiro Wilk & Df & Sig \\
\hline Experimental & 0,793 & 36 & 0 \\
$\quad$ Group & 0,696 & 36 & 0 \\
Control Group & & & \\
\hline
\end{tabular}

The same rule is also applied for the post-test normality data test. The posttest obtains a result of significance score for experimental group is 0 and the control group is 0 . It meant both scores' significances were not normally distributed because they were lesser than the significant score, 0.05 . The normality data test conclusion was based on the comparison between the counted significance and the significance level, 0.05 . Based on the statistics result with Shapiro Wilk, the pretest-posttest data in Table 2 and Table 3 have significances lower than 0.05 . Thus, the data were not normally distributed. Therefore, the hypothesis test used the non-parametric statistics test, the Mann Whitney test (U-test).

Then, the next one was the homogeneity test of pretest-posttest of both groups with Levene test. This test had the purpose to ensure both groups were from the homogeneous sample. In this test, data with non-normal distribution can be used but the data should be continuous. The Levene test of both groups' pretests is shown in Table 4.

Table 4. The Homogeneity Data Test of both Groups' Pretests with Levene Test

\begin{tabular}{cccc}
\hline The Levene Test & Df 1 & Df 2 & Sig. \\
\hline 3,591 & 1 & 70 & 0,062 \\
\hline
\end{tabular}

Data is considered homogeneous if the significance based on the mean is 0.05 . If the significance-based mean higher than 0.05 , the data variance of the pretest is considered homogeneous and vice versa. Table 4 shows the homogeneity test results of both groups' pretests. They obtain a significance of 0.062 , higher than 0.05 . Thus, the data are from both groups are homogeneous. Then, the homogeneity test results of both groups' posttest could be seen in Table 5 . 
Table 5. The Homogeneity Test of both Groups' Posttest Data with the Levene Test

\begin{tabular}{cccc}
\hline \multicolumn{4}{c}{ The Posttest Results of both Groups } \\
\hline The Levene test & Df 1 & Df 2 & Sig. \\
1,723 & 1 & 70 & 0,194 \\
\hline
\end{tabular}

The posttest data homogeneity can be determined from the comparison of the calculation and the significance-based on mean, 0.05 . If the significance score is higher than 0.05 , then the data variance of the posttest is homogeneous and vice versa. Table 5 shows the posttest data results of both groups obtain a significance of 0.194 , higher than 0.05 . Thus, it can be concluded the data are homogeneous.

The hypothesis test of this research used Mann Whitney since the normality test proved the data were not normally distributed. Therefore, this research used the independent sample test with two samples from experimental and control groups. In this case, they were not correlated at all. The hypothesis of the posttest data for both groups is shown in Table 6.

Table 6. The Hypothesis Test of both Groups' Posttest with Mann Whitney test

\begin{tabular}{cc}
\hline Tests & Learning Outcomes \\
\hline Mann-Whitney $U$ & 333.500 \\
\hline Wilcoxon $W$ & 999.500 \\
\hline$Z$ & -3.677 \\
\hline Asymp. Sig. (2-tailed) & .001 \\
\hline
\end{tabular}

The decision based on the statistics test is if the Zcount lower than the Ztable and the significance is higher than 0.05 , Ho is accepted while $\mathrm{Ha}$ is denied and vice versa. Table 6 shows the hypothesis test of both groups' posttest data obtained a Z score of -3.677 (either positive or negative is not calculated). The direction of the $\mathrm{Z}$ count was compared with the Ztable, -1.96 . The Zscore and the significance score of the posttest showed Zcount higher than Ztable (-3.677 > -1.96) and the significance (2-tailed) 0.001 or lesser than 0.05 . Thus, Ho is denied and $\mathrm{Ha}$ is accepted. It means the self-regulated learning-based problem solving influenced the learners' learning outcomes.

\section{The Influence Self-Regulated Learning Strategy based Problem Solving of the Experimental Group}

The experimental group's learning was done by providing problems related to simple harmonic motion in the student worksheet. Here is the example of the presented question in the worksheet for the third meeting (Figure 1).

2. Sebuah benda menempuh gerak harmonic sederhana dengan amplitude $A$ dan periode T. Tentukan :

a. Waktu minimum yang diperlukan benda agar simpangannya sama dengan setengah amplitudonya

b. Simpangan ketika kecepatannya setengah dari kecepatan maksimumnya

Figure 1. The problem questions to solve by learners 
In the first stage, the learners identified the problems. The learning was begun by the teacher's explanation about the material with PPT slides. The teacher-directed the learners to share their opinion about the given main problems. After discussing and analyzing the discussion topic, learners wrote what they knew about the presented problem in the worksheet. This stage required students to find out and write what was asked by the questions as the presented problems.

In the second stage, learners were guided to determine the objectives of the problem solutions. This stage required the students to find and analyze the information accurately. They also had to decide whether they would use it or not solve problems. Learners could write the strategies of question problem solution correctly by writing the deviation equation $y=A \sin \left(\frac{2 \pi t}{T}\right)$. It was the initial strategy to determine the next solution based on the problems.

In the third stage, learners explored the possible strategies to solve problems. The teacher-directed the learners to operate and to solve the questions based on the arranged plan orderly and correctly. This stage emphasized inter-peer discussion to develop personal thinking awareness about what strategy should be applied during the situation. The learners could explore the question solution by operating the deviation equation to obtain the t-period. It was to ensure the deviation was half of the amplitude. Then, they had to find the deviation when the velocity was half of the maximum velocity by writing the equation of $v=v_{m} \cos \theta$. It obtained a result of $60^{\circ}$ to determine the final deviation magnitude. The learners' answers could be seen in Figure 2.
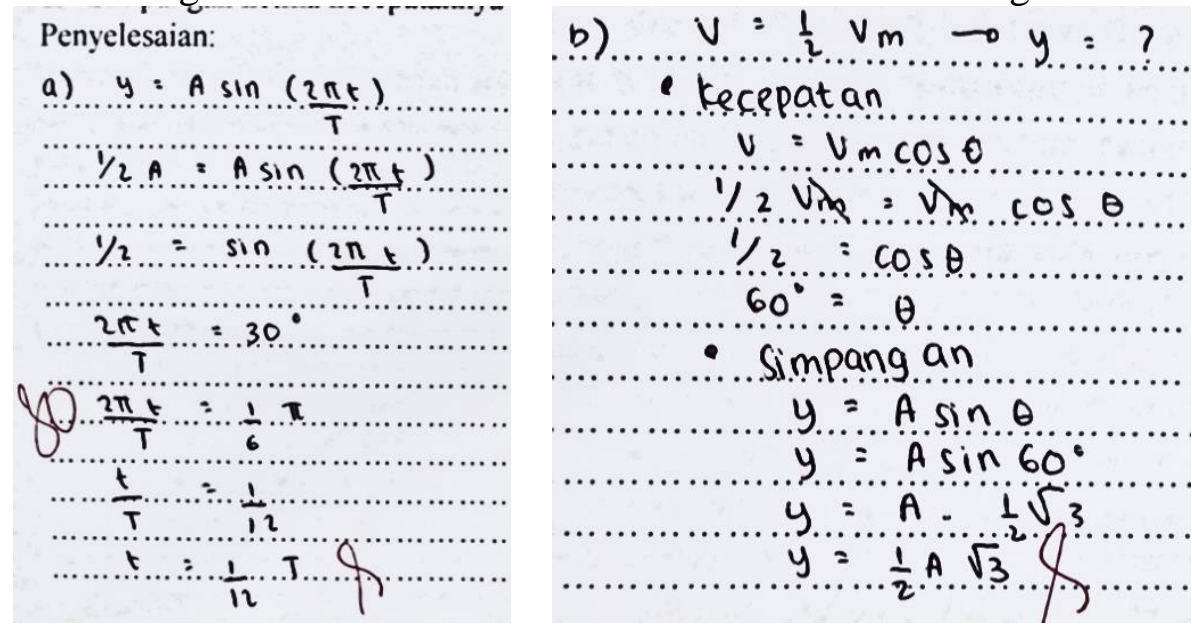

Figure 2. The answers to the questions by the learners

In the fourth stage, the learners anticipated the results and acted out. The teacher emphasized the discussed materials on the presented problems. It was to make them understand, remember, and believe in their answers. The learners were asked to evaluate their learning process while using the strategies or determining the problem solution. They had to be careful in operating the equation and process the data based on the given physics problems.

The fifth stage required the learners to be guided, to check again, and to learn from the problem-solution process. The learners had a chance to conclude. It was their emphasis on the question solution methods. They also obtained the correct answers. The 
learners reviewed the question by connecting to the previous materials given by the teacher.

In the sixth stage, the learners created journals of self-regulation. They reviewed the learning process by filling the journal and handed the journal to the teacher. The teacher-directed the journal filling so that learners could review their learning outcomes honestly. This journal was the medium for the learners to reflect on their learning processes.

The journal allowed both learners and teachers to trace the conceptual understanding and learning outcomes. The improvement of the learning outcomes could be noticed because the learners were asked to reflect on the physics learning process (Orsini, et al., 2015). The journal implementation for self-regulation was supported by some previous studies. They found the influence of SRL with autonomous journal filling toward the academic achievements for primary school and Junior high school learners in China. SRL had the greatest effects on mathematics and physics science. The performance and self-reflection phases were the keys to autonomous learning $(\mathrm{Li}$, et al., 2018). SRL could improve the learning outcomes and be suitable for exact learning based on the previous findings (Tan, 2004; Winarti \& Saputri, 2013).

\section{The Influence of Learning Outcomes Improvement with Self-Regulated Learning-based Problem-Solving of the Experimental Group}

The different learning strategies stages for both groups caused differences in learning outcome improvement in solving problems. The findings were also supported by the learners' answers while the posttest and pretest. The posttest results of the learners are shown in Figure 3.

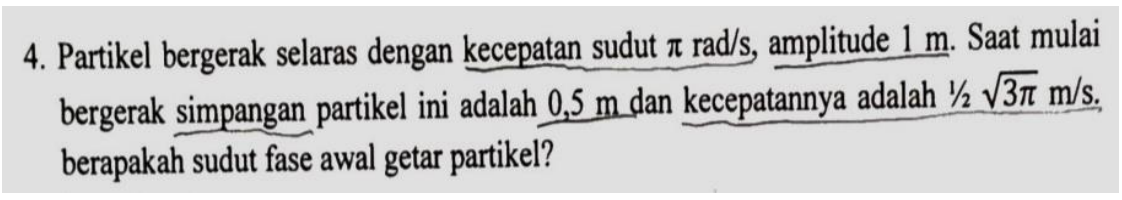

Figure 3. The Posttest Question Items

In this first stage, both groups' learners wrote what they knew from the question about the angular velocity $\omega$, with a magnitude of $\pi \mathrm{rad} / \mathrm{s}$, amplitude $A$ with $1 \mathrm{~m}$, and deviation $y$ with $0.5 \mathrm{~m}$, and the particle velocity $v$ with $\frac{1}{2} \sqrt{3 \pi} \mathrm{m} / \mathrm{s}$.

In the second stage, the experimental group of learners chose the equation based on what they knew from the question to determine the size of the angle. The experimental group of learners wrote the deviation equation. It was $y=A \sin (\omega t+\theta)$ as the way to solve the question. On the other hand, the control group determined the solution by writing the equation of $\varphi^{2}=\omega^{2}\left(A^{2}-y^{2}\right)$ to solve the questions. The learners' answers are shown in Figure 4. 


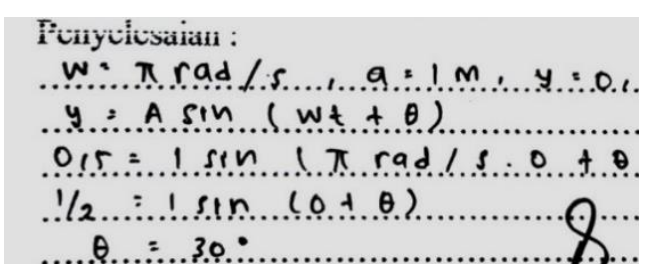

a.

Figure 4. The learners' answers (a) the experimental group (b) the control group

In the third stage, the learners solve problems by operating the obtained equation. The research found some differences in the problem-solving skills of the second stage could improve the next stage. The experimental group learners could operate the data from the deviation equation $y=A \sin (\omega t+\theta)$ excellently and carefully. Therefore, learners of the experimental group could obtain the correct solution and results from the phase angle of the initial phase angle of the particle vibration. The control group learners operated the initial equation to find the initial phase angle of the particle vibration and the deviation equation but they did it incorrectly. These matters occurred in the analysis process.

In the fourth stage, teachers emphasized the experimental group learners to check the recognized data and to operate the data into the applied equation. On the other hand, for the control group, the teacher did not remind but warned the students to encourage their learning process and to review their works.

The final stage of the experimental group learners was writing the final result emphasis after operating the data into the equation. On the other hand, the control group did not obtain any emphasis from the teacher. Thus, they did not write the conclusion because they might forget to write or they did not find the solution. The learners' learning outcome improvements were significant based on the $\mathrm{N}$-Gain average score (Table 7).

Table 7. The N-Gain Average Score Descriptions

\begin{tabular}{cccc}
\hline Groups & $\mathbf{N}$ & $\boldsymbol{N}$-Gain & Categories \\
\hline $\begin{array}{c}\text { Experimental } \\
\text { Group }\end{array}$ & 36 & 0,5904 & Moderate \\
$\begin{array}{c}\text { Control } \\
\text { Group }\end{array}$ & 36 & 0,3065 & Moderate \\
\hline
\end{tabular}

The experimental group's N-gain is higher than the control group. It is 0.590 higher than 0.3065 . Thus, the experimental group is categorized as moderate. The SRL- 
based problem solving was effective to improve the learning outcomes of the learners than the discovery learning. Based on the indicators and stages of problem solving with the self-regulated learning strategy used in physics learning, it is able to train learners' in working on physics problems in a coherent and precise manner in accordance with the correct problem solving flow. Learners' are also trained to choose which method is appropriate for problem solving in each of the problem models presented. This finding was supported by previous studies that identified the outcome difference of SRL and discovery learning implementations (Manlove \& Lazonder, 2004).

\section{CONCLUSION}

The hypothesis test results of both groups' posttest data obtained a greater Zcount than the Ztable. Thus, self-regulated learning-based problem solving influenced the learners' learning outcomes. The improvement was found based on the $\mathrm{N}$-gain average score, categorized moderate. So, self-regulated learning strategy based problem solving can be applied in physics learning to support improvement learners' learning outcomes. Further researchers can modify the strategi self-regulated learning based on problem solving or create new strategies to improve learners' learning outcomes.

\section{REFERENCES}

Adolphus, T., Alamina, J., \& Aderonmu, T. (2013). The Effects of Collaborative Learning on Problem Solving Abilities among Senior Secondary School Physics Students in Simple Harmonic Motion. Journal of Education and Practice, 4(25), 95-101.

Agusni, H. P., Abdurrahman, \& Wahyudi, I. (2017). Pengaruh Skill Argumentasi Menggunakan Model Problem Based Learning Terhadap Hasil Belajar Siswa. Jurnal Pembelajaran Fisika, 5(4), 97-104.

Aiken, L. R. (1980). Content Validity and Reliability of Single Items or Questionnaires. Educational and Psychological Measurement, 40(4), 955-959. https://doi.org/10.1177/001316448004000419

Anggo, M. (2011). Pelibatan Metakognisi dalam Pemecahan Masalah Matematika. Edumatica, 1(1), 25-32.

Armelia, M. N., \& Ismail. (2021). Pengaruh Self-Regulated Learning terhadap Kemampuan Berpikir Reflektif Matematis Siswa. Jurnal Cendekia: Jurnal Pendidikan Matematika, 5(2), 1757-1768.

Ayu, N. M., Rosidin, U., \& Viyanti, V. (2014). Pengembangan Instrumen Penilaian Keterampilan Metakognisi Pada Pembelajaran IPA di SMP. Jurnal Pembelajaran Fisika, 2(5), 135-146.

Blakey, E., \& Spence, S. (1990). Developing Metacognition. In ERIC Clearinghouse on Information and Technology. Retrieved from http://www.nagc.org/index.aspx?id=205 
Bransford, J. D., \& Stein, B. S. (1993). The Ideal Problem Solver: A Guide for Improving Thinking, Learning, and Creativity (2nd ed.). New York: W. H. Freeman \& Co.

Chairani, Z. (2013). Aktivitas Metakognisi Sebagai Salah Satu Alat untuk Meningkatkan Kemampuan Siswa dalam Pemecahan Masalah Matematika. Konferensi Nasional Pendidikan Matematika V, (1), 652-659. Malang: FMIPA UM.

Friskilia, O., \& Winata, H. (2018). Regulasi Diri (Pengaturan Diri) Sebagai Determinan Hasil Belajar Siswa Sekolah Menengah Kejuruan. Jurnal Pendidikan Manajemen Perkantoran, 3(1), 184. https://doi.org/10.17509/jpm.v3i1.9454

Gagne, R. M. (1985). The Conditions of Learning (4th ed.). New York: Holt, Rinehart \& Winston.

Himawan, N. A., Jumadi, J., \& Purwanto, E. (2020). Identifikasi Kemampuan Penalaran Siswa Kelas XI di MAN 4 Bantul pada Suhu dan Kalor. Edusains, 12(1), 30-37. https://doi.org/10.15408/es.v12i1.12784

Himawan, N. A., \& Winarti, W. (2018). Strategi Metakognisi untuk Meningkatkan Kemampuan Pemecahan Masalah pada Materi Teori Kinetik Gas. Edusains, 10(2), 265-274. https://doi.org/10.15408/es.v10i2.8021

Iskandar, S. M. (2014). Pendekatan Keterampilan Metakognitif dalam Pembelajaran Sains di Kelas. Erudio Journal of Educational Innovation, 2(2), 13-20. https://doi.org/10.18551/erudio.2-2.3

Lee, M., \& Baylor, a L. (2006). Designing Metacognitive Maps for Web-Based Learning. Educational Technology \& Society, 9(1), 344-348.

Lestari, N. A., Widada, W., \& Zamzaili. (2017). Pengaruh Strategi Pembelajaran Self Regulated Learning in Mathematics Berbasis Pemecahan Masalah Terhadap Kemampuan Metakognitif Siswa di SMA Negeri 2 Bengkulu. Jurnal Pendidikan Matematika Raflesia, 2(2), 188-160.

Li, J., Ye, H., Tang, Y., Zhou, Z., \& Hu, X. (2018). What Are the Effects of SelfRegulation Phases and Strategies for Chinese Students? A Meta-Analysis of Two Decades Research of the Association Between Self-Regulation and Academic Performance. Frontiers in Psychology, 9(December), 1-13. https://doi.org/10.3389/fpsyg.2018.02434

Lin, S. Y., \& Singh, C. (2011). Using Isomorphic Problems to Learn Introductory Physics. Physical Review Special Topics-Physics Education Research, 7(2). https://doi.org/10.1103/PhysRevSTPER.7.020104

Livingston, J. A. (2003). Metacognition: an Overview. In Educational Research and Information Center. Retrieved from http://gse.buffalo.edu/fas/shuell/CEP564/Metacog.htm

Mahen, E. C. S., \& Nuryanti, A. Y. (2018). Profil Pemahaman Konsep Calon Guru Fisika pada Materi Gerak Harmonik. Physics Communication, 2(1), 18-25. 
Malik, A., Nuraeni, Y., Samsudin, A., \& Sutarno, S. (2019). Creative Thinking Skills of Students on Harmonic Vibration using Model Student Facilitator and Explaining (SFAE). Jurnal Ilmiah Pendidikan Fisika Al-Biruni, 8(1), 77-88. https://doi.org/10.24042/jipfalbiruni.v8i1.3056

Manlove, S., \& Lazonder, A. (2004). Self-Regulation and Collaboration in a Discovery Learning Environment. In First Meeting of the EARLI-SIG on Metacognition. Amsterdam: The Netherlands.

Merhar, V. K., Planinsic, G., \& Cepic, M. (2009). Sketching Graphs-An Efficient Way of Probing Students' Conceptions. European Journal of Physics, 30(1), 163175. https://doi.org/10.1088/0143-0807/30/1/017

Nahdi, D. S., \& Juju. (2016). Peningkatan Kemampuan Self-Regulated Learning (SRL) Siswa Sekolah Dasar Melalui Model Pembelajaran Kooperatif Tipe Think Pair Share (TPS). Jurnal Cakrawala Pendas, 2(1).

Orsini, C., Evans, P., \& Jerez, O. (2015). How to Encourage Intrinsic Motivation in the Clinical Teaching Environment?: a Systematic Review from the SelfDetermination Theory. Journal of Educational Evaluation for Health Professions, 12(8).

Qohar, A., \& Sumarmo, U. (2013). Improving Mathematical Communication Ability and Self Regulation Learning of Yunior High Students by Using Reciprocal Teaching. Indonesian Mathematical Society Journal on Mathematics Education, 4(1), 59-74. https://doi.org/10.22342/jme.4.1.562.59-74

Rahayu, S., \& Hertanti, E. (2020). Students' Metacognitive Awareness and Physics Problem Solving ability and Correlation Between Them. Jurnal Ilmiah Pendidikan Fisika Al-Biruni, 9(2), 207-215. https://doi.org/10.24042/jipfalbiruni.v9i2.6009

Rerung, N., Sinon, I. L. ., \& Widyaningsih, S. W. (2017). Penerapan Model Pembelajaran Problem Based Learning (PBL) untuk Meningkatkan Hasil Belajar Peserta Didik SMA pada Materi Usaha dan Energi. Jurnal Ilmiah Pendidikan Fisika Al-Biruni, 6(1), 47-55. https://doi.org/10.24042/jpifalbiruni.v6i1.597

Santrock, J. W. (2007). Psikologi Pendidikan (2nd ed.). Jakarta: Kencana Prenada Media Group.

Saputra, A. T., Jumadi, J., Paramitha, D. W., \& Sarah, S. (2019). Problem-Solving Approach in Multiple Representations of Qualitative and Quantitative Problems in Kinematics Motion. Jurnal Ilmiah Pendidikan Fisika Al-Biruni, 8(1), 89-98. https://doi.org/10.24042/jipfalbiruni.v8i1.3801

Sugara, Y. D., Sutopo, \& Latifah, E. (2016). Kesulitan Siswa SMA dalam Memahami Gerak Harmonis Sederhana. Prosiding Seminar Pendidikan IPA Pascasarjana $U M, 1$, 506-512. Malang: Pascasarjana UM.

Sulisworo, D., Fatimah, N., Sunaryati, S. S., \& Sanidi. (2020). A Quick Study on SRL Profiles of Online Learning Participants During the Anticipation of the Spread of COVID-19. International Journal of Evaluation and Research in Education, 9(3), 723-730. https://doi.org/10.11591/ijere.v9i3.20642 
Susanto, A. (2013). Teori Belajar dan Pembelajaran Di Sekolah Dasar. Jakarta: Kencana Prenadamedia Group.

Tan, O. S. (2004). Cognition, Metacognition, and Problem-Based Learning, in Enhancing Thinking Through Problem-Based Learning Approaches. Singapore: Thomson Learning.

Winarti, W., \& Saputri, A. A. (2013). Pengembangan Modul Fisika Berbasis Metakognisi pada Materi Pokok Elastisitas dan Gerak Harmonik Sederhana. Jurnal Psikologi Integratif, 1(1), 187-195.

Winiari, L. P., Santyasa, I. W., \& Suswandi, I. (2019). Pengaruh Model Seld Regulated Learning terhadap Kemampuan Berpikir Kritis dalam Pembelajaran Fisika Kelas XI MIA di SMA Negeri 1 Tembuku. Jurnal Pendidikan Fisika Undiksha, 9(1), 24-25. Retrieved from https://ejournal.undiksha.ac.id/index.php/JJPF/article/view/20646

Yanti, H., Distrik, I. W., \& Khasyyatillah, I. (2017). Profile of Senior High School Metacognitive Ability in Solving Problems of Abstraction on Physics Material. Jurnal Ilmiah Pendidikan Fisika Al-Biruni, 6(2), 241-246. https://doi.org/10.24042/jipfalbiruni.v6i2.2061

Zimmerman, B. J. (1989). A Social Cognitive View of Self-Regulated Academic Learning. Journal of Educational Psychology, 81(3), 329-339. https://doi.org/10.1037/0022-0663.81.3.329 